\title{
Guided discovery model: An alternative to enhance students' critical thinking skills and critical thinking dispositions
}

\author{
Sri Hastuti Noer \\ Department of Mathematics and Science Education, Faculty of Teacher Training and Education, \\ Universitas Lampung. Jl. Prof. Dr. Sumantri Brojonegoro No. 1, Bandar Lampung, 35145, Indonesia \\ * Corresponding Author. Email: hastuti_noer@yahoo.com \\ Received: 9 November 2017; Revised: 8 March 2018; Accepted: 30 April 2018
}

\begin{abstract}
This current study aimed to determine the effectiveness of the guided discovery model in increasing students' critical thinking skills and critical thinking dispositions. Each experiment and control group consisted of 34 students of grade X of one high school class in Bandar Lampung city. The data were obtained through mathematical critical thinking skills test and critical thinking dispositions scale. The data were analyzed qualitatively and quantitatively to obtain a comprehensive description of the impact of learning on the increase in both skills. The results showed that the increase of students' critical thinking skills and critical thinking dispositions after learning was in the effective category. Other finding showed that the use of a contextual problem in the beginning of learning could trigger students to activate their prior knowledge. In this way, students used some strategies and made an appropriate conclusion confidently. This study suggested that the guided discovery model can be an alternative to improve students' critical thinking skills and critical thinking dispositions.
\end{abstract}

Keywords: guided discovery model, critical thinking skills, critical thinking dispositions

How to Cite: Noer, S. (2018). Guided discovery model: An alternative to enhance students' critical thinking skills and critical thinking dispositions. Jurnal Riset Pendidikan Matematika, 5(1), 108-115. doi:http://dx.doi.org/10.21831/jrpm.v5i1.16809

Permalink/DOI: http://dx.doi.org/10.21831/jrpm.v5i1.16809

\section{INTRODUCTION}

Mathematics essentially as a structured and systematic science, as a human activity through an active, dynamic, and generative process, and as a science that develops a critical, objective, and open-minded attitude; become very important to be mastered by learners in facing the rapid rate of science and technology change. Through mathematics learning, critical thinking skills can be developed. Along with the critical thinking skills that must be developed, there is a mathematical disposition as well must be developed simultaneously. In learning mathematics, the development of mathematical disposition will form the desire, awareness, dedication and strong tendency in students to think and do mathematically in a positive way.

Unlike the traditional education concept those are learning takes place in the order of: (1) giving lesson material by teacher, (2) giving sample of problem, and (3) giving of practice; the concept of current education is more emphasis on the progress and development of educational philosophy. It is intended to give the individual an opportunity to explore their potentials and abilities. In the world of current education, the school should be the vehicle to produce students who possess critical knowledge. Therefore, the school should provide opportunities for developing critical thinking skills. It is stated by McLaren \& Baysal (2007), "schools should promote collective imaginations items, namely critical thinking mentions roommates establishing social justice for all groups, and ending all discrimination, such as exploitation, racism and sexism".

Critical thinking is the kind of thinking that is based on individual questions about the thinking process itself and others (Kilic \& Sen, 2014) which depends on the conditions of the current situation and requires specific skills and responsibilities (Lipman, 1988). Critical thinking is a decision activity based on the evidence, concepts, methods, criteria and conditions, and depends on the purpose of making the interpretation, analysis, evaluation and conclusion 
(P. A. Facione, 1990). Therefore, it can be concluded that critical thinking requires the individual not only to observe the conditions as shown, but also to question and make a conclusion.

Critical thinker usually has high interest towards something, eager to rethink, accustomed to a complex problem, behave carefully for information, rational in selecting the criteria and persistent in achieving results (N. C. Facione \& Facione, 1996; P. A. Facione, 1990, 2000). But unfortunately, most of the students are rarely given the opportunity to exercise their critical thinking skills in learning. Generally, the learning experiences are only listening to the teacher's explanation of the subject matter and example of problems, and doing exercise that is similar to what the teacher gives before. They rarely challenged with non-routine problems, so they are required to see information from various sources, question the validity of the source, choose a reliable source, process information, and make conclusions. In this way, they will have the ability to think critically and have a strong belief about the ability of thinking. Many students who have graduated from high school may never face a challenging situation that requires critical thinking dispositions. It can be seen from the fact when they were studying at a higher education level; they often miss a chance when facing the tasks that require critical thinking or problem-solving skills. Often they even ask, "How do we solve this problem?". It is also raised by Rapps, Riegel \& Glaicer in Noddings (2004) that many students rarely use critical thinking skills when facing the situations that require ability to think carefully.

Innabi (2003) classified aspects of critical thinking in two types, namely critical thinking of general aspects and critical thinking of content-related aspects. Nursyahidah \& Albab (2017) stated that critical thinking process involves many aspects of working to solve problem, and one of it is content-related aspects. Critical thinking on content-related aspects includes four sub aspects: concepts, generalizations, algorithms and skills, and problem solving. Nosich (1994) said that critical thinking requires more than high order thinking skills. By definition, critical thinking is also included in the high order thinking skills those are focused on logical decision-making, obtain and assess information (Ennis, 1987; Ragatz, 2010; Schaefer, 2012; Uygulamaya \& Demirel, 2002), and problem solving (Chance, 1986; Halpern,
2013). Similarly, Kennedy, Fisher, \& Ennis (1991) stated that the critical thinking skills require the ability to identify and focus on the problem to understand and assess the validity and consistency of the hypothesis and information. This capability is an important provision for the individual to adapt the era of globalization in the present and the future. With this capability, an individual can select and sort the information needed to solve the problems in their life.

Abdurahim (2016) stated that critical thinking skills and information processing skills (including information gathering skills, classifying, sorting, comparing, contrasting and analyzing the parts and connections as a whole) are related to inquiry skills. It deals with activities to address and define problems, plan what to do and how to conduct investigations, make predictions of results and anticipate the consequences.

In overcoming problem that requires critical thinking, beliefs about one's ability to think critically will affect their ability to cope with problems. Likewise, someone who trained to solve complex problems will be honed their critical thinking skills. Therefore, someone will more confident with his/her ability anyway. The development of students' critical thinking skills by itself will improve their critical thinking disposition. A number of taxonomies of critical thinking dispositions have been developed e.g. Ennis (1987), P. A. Facione, Facione, \& Giancarlo (1996).

The current condition of mathematics learning in schools is not aligned with the important role of mathematics. According to Yohanes (2010), learning strategies commonly used by teachers are: (1) $52 \%$ of the time used to explain while students listen and answer the questions posed by the teacher; (2) $20 \%$ of the time used for problem solving; (3) time spent on discussions, practical work and investigations, respectively $15 \%, 10 \%$ and $3 \%$. It appears that in the learning process, students are rarely given the opportunity to learn independently. Mettes in Ibrahim (2011) said that generally in mathematics learning, students only modeled and recorded how to resolve a problem that has been done by the teacher. If the students are given a different problem, they are difficult to resolve. It was making the students think that mathematics is a difficult subject and unpleasant.

The vision of mathematics education has two directions of development, which meets the needs of the present and the future. With such a 
vision, it requires that educators need to think the right way in preparing students to be ready to accept the challenge of the present and the future. For that goal, teachers need to design learning activities that allow students to develop mathematics skills including critical thinking skills and critical thinking dispositions. Liberma (2013) stated that critical thinking is a very important skill for everyone. It is used to solve the problem of life with serious thinking, active, conscientious and analyze all received information including rational reason, so that any action taken is correct.

Considering the importance of critical thinking skills and the gap between the vision of mathematics and mathematics learning conditions, it is necessary to improve the learning process. There are several ways to do to overcome these problems, one of which is guided discovery learning model. In this model, learning process is not left entirely to the students, but the teacher still act as counselors when needed. Learning invention reduces direct instruction from the teacher and makes students to construct their own knowledge. Yang, Liao, Ching, Chang, \& Chan (2010) stated that guided discovery learning makes students get more deep informations in the learning. In guided discovery learning, teachers help students to study and guide the students that have difficulty.

Guided discovery learning teaches students finding an idea, thinking critically, questioning, and problem resolution. For educate students to investigate and resolve the problems they face, it is believed that the method by constructivist approach makes students learn more effective by building their own knowledge. One method that can be used for that goal is guided discovery learning (Balım, 2009). Guided discovery learning has several advantages. The advantages include: (1) help students to develop and multiply readiness, as well as master skills in cognitive processes; (2) help students to acquire knowledge individually so knowledge will stay long in the minds of the students; (3) excite students learning; (4) provide an opportunity for students to develop and progress according to their ability; (5) direct how students learn, so they have a strong motivation to study hard; (6) help students to strengthen and increase the confidence in themself to the process of selfdiscovery. The following paper presents the research conducted to obtain an overview of the effects of guided discovery learning to increase students' critical thinking skills and critical thinking dispositions.

\section{METHOD}

This research was an experiment research. This research applied the discovery learning model using pre-test and post-test control group design to see the effect of learning method to increase students' critical thinking skills and critical thinking dispositions. The population in this research was all students of a senior high school in Lampung. By using purposive random sampling technique, it was selected 34 students of class X.3 as control group with conventional learning and 34 students of class X.4 as experiment group with guided discovery learning. The study began with taking pre-test in the experiment and control class, then conducting guided discovery learning in the experiment class and conventional learning in the control class, then performing post-test in both classes. In this study, the guided discovery learning stages are: (a) the teacher gives the problem through the student worksheet, (2) the students prepare, process, organize, and analyze the problem, (3) the teacher guides students as far as needed, (3) termination of conjecture by students based on their analysis, (4) examination of conjectures students have made, and (5) verbalization of conjecture by students.

Instruments used in this study consisted of two types of instruments, namely non-test and test. Non test instruments used were interview guidelines and questionnaire. Interview guidelines are used during preliminary studies to find out the initial conditions of students and the teaching materials used in schools. Other nontest instrument, which is questionnaire, is used in several stages of research: (1) validation of syllabus and lesson plan, (2) validation of student worksheet, (3) validation of student worksheet testing, and 4) measurement of critical thinking dispositions.

To validate the syllabus and lesson plan, a questionnaire was given to two mathematics teachers. Likert scale Questionnaire with four choices of answers (Very Good (VG), Good (G), Less (L), and Very Less (VL)) is used and it comes with comments and suggestions from teachers. The criteria used in the validation questionnaire of the syllabus are: (1) Feasibility aspects of the content, including the suitability of the syllabus with the basic competence and indicators, the learning activities designed based on guided discovery; (2) Aspects of language 
feasibility, including the use of language in accordance with Ejaan Yang Disempurnakan (EYD), the simplicity of sentence structure; and (3) The time eligibility aspect, including the appropriateness of time allocation with the basic competence. The criteria used in the validation questionnaire of the lesson plan are: (1) Eligibility aspects of the objectives, including conformity of lesson plan with basic competence, accuracy of basic competence translation into indicator; (2) Feasibility aspects of the content, including the systematic preparation of lesson plan, learning scenarios designed based on guided discovery; (3) Aspects of language feasibility, including the use of language in accordance with EYD, communicative and simplicity of sentence structure; and (4) Time eligibility aspects, including the appropriateness of time allocation selection based on basic competence.

Student worksheet validation instruments are given to material experts and media experts. Likert scale instrument with four choices of answers (Very Good (VG), Good (G), Less (L), and Very Less (VL)) is used and it comes with comments and suggestions from experts. The criteria of the assessment of the material expert are: (1) Aspects of feasibility of content, including the material conformity with the basic competence, the accuracy of the material; (2) Aspects of feasibility of presentation, including techniques, completeness, coherence and the demands of thought processes; and (3) Aspects of assessment of guided discovery learning strategies. The criteria of the assessment of the media expert are: (1) Aspect of feasibility of ergonomics, including design of student worksheet content; and (2) Aspects of language feasibility, including engagement, communicative, dialogical and interactive, conformity with student development, conformity with language rules, and use of terms and symbols.

Questionnaire of student worksheet testing is used to determine the aspect of legibility and attractiveness. This instrument is statements with four choices of answers (Very Good (VG), Good (G), Less (L), andVery Less (VL)).

The test of critical thinking skills and the scale of critical thinking dispositions are used in this research to collect the data. The test used to measure critical thinking skills was developed from descriptions and indicators of critical thinking abilities. The indicators measured in the test are: (1) exploration, (2) identify and justify the concept, (3) generalization, (4) clarification and resolution. Critical thinking dispositions scale is given to students to measure students' critical thinking dispositions. The instrument used was developed by referring to indicators developed by P. A. Facione, Sanchez, Facione, \& Gainen (1995), namely: (1) Open-mindedness, (2) Inquisitiveness, (3) Systematicity, (4) Truth-seeking, (5) Analyticity, (6) SelfConfidence, and (7) Maturity. Critical thinking dispositions scale is compiled by Likert scale with four choices: strongly agree (SA), agree (A), disagree (DA), and strongly disagree (SDA), with no neutral option. It is intended to avoid the attitude of students that hesitate to pick a proposed statement. To determine the differences in critical thinking skills and critical thinking dispositions of students who take different learning method (guided discovery learning and conventional learning) is performed statistical analysis covering normality test and homogeneity of variance. Furthermore, determining the difference between two groups of samples was done by using t-test.

\section{RESULT AND DISCUSSION}

The data of mathematics critical thinking skills is obtained through a pre-test and post-test conducted at the beginning and the end of the learning. Hypothesis testing was done using ttest. Descriptive analysis pre-test scores of students in guided discovery learning and conventional learning are presented in Table 1.

Table 1. The Data of Pre-test on Mathematics Critical Thinking Skills

\begin{tabular}{cccccc}
\hline Learning Method & The Number of Students & Average & Lowest Score & Highest Score & Standard Deviation \\
\hline Guided discovery & 34 & 54.78 & 37.5 & 68.75 & 7.70 \\
Conventional & 34 & 52.38 & 37.5 & 68.75 & 8.28 \\
\hline
\end{tabular}

Table 2. t-test Results of Pre-test on Critical Thinking Skills

\begin{tabular}{ccccc}
\hline Data & t-value & Df & Sig. $(2$ - tailed $)$ & Category \\
\hline Pretest & 1.232 & 66 & 0.222 & Sig. $(2-$ tailed $)>0,05$ \\
\hline
\end{tabular}


Jurnal Riset Pendidikan Matematika, 5 (1), 2018 - 112

Sri Hastuti Noer

Table 3. The Data of Post-test on Mathematics Critical Thinking Skills

\begin{tabular}{cccccc}
\hline Learning Method & The Number of Students & Average & Lowest Score & Highest Score & Standard Deviation \\
\hline Guided discovery & 34 & 79.78 & 62.50 & 93.75 & 7.85 \\
Conventional & 34 & 59.37 & 43.75 & 75 & 7.83 \\
\hline
\end{tabular}

Table 4. t-test Results of Post-test on Critical Thinking Skills

\begin{tabular}{ccccc}
\hline Data & t-value & Df & Sig. (2-tailed) & Category \\
\hline Posttest & 10.69 & 66 & 0,00 & Sig. $(2$ - tailed $)<0,05$ \\
\hline
\end{tabular}

Tabel 5. The Data of Post-test on Critical Thinking Dispositions

\begin{tabular}{lccccc}
\hline Learning Method & $\begin{array}{c}\text { The Number } \\
\text { of Students }\end{array}$ & Average & Lowest Score & Highest Score & Standard Deviation \\
\hline Guided discovery & 34 & 74.30 & 67.24 & 83.62 & 3.84 \\
\hline Conventional & 34 & 70.51 & 63.79 & 85.62 & 4.40 \\
\hline
\end{tabular}

The data in Table 1 illustrates that the lowest scores, highest scores, and average of prior knowledge of students who take guided discovery learning and conventional learning are relatively the same. The data were analyzed using t-test to determine whether there is a significant difference in the average score of the pre-test between mathematics critical thinking skills of students who take guided discovery learning and conventional learning. The summary of t-test results of pre-test scores is presented in Table 2.

Based on Table 2, it can be concluded that there was no significant difference in the average score of the pre-test between mathematics critical thinking skills of students who take guided discovery learning and conventional learning. This indicated that the prior knowledge of two classes do not differ significantly. The descriptive analysis of post-test scores of students who take guided discovery learning and conventional learning is presented in Table 3.

The data in Table 3 illustrates that the lowest, highest, and average of score on mathematics critical thinking skills of students who take the guided discovery learning are higher than students who take the conventional learning. Furthermore, the data of post-test score from both classes were analyzed by using t-test to determine whether there is a difference on mathematics critical thinking skills. The summary of t-test result of post-test scores are shown in Table 4.

Based on Table 4, it can be concluded that there is a significant difference between critical thinking skills of students who take the guided discovery learning and conventional learning.

The data of critical thinking dispositions in this research was obtained through post-test conducted at the end of learning. Hypothesis testing was done by using t-test with SPSS for windows. The descriptive analysis of post-test scores of students who take guided discovery learning and conventional learning are presented in Table 5.

The data in Table 5 illustrates that the lowest, highest, and average score of students' critical thinking dispositions that follow the guided discovery learning and conventional learning look different. Furthermore, these two classes' score were analyzed by using t-test to determine whether there is a significant difference.

The summary of t-test result of critical thinking dispositions are presented in Table 6.

Table 6. t-test Results of Post-test on Critical Thinking Dispositions

\begin{tabular}{ccccc}
\hline Data & t-value & Df & $\begin{array}{c}\text { Sig. } \\
(2-\text { tailed })\end{array}$ & Category \\
\hline Posttest & 3.77 & 64 & 0,000 & $\begin{array}{c}\text { Sig. }(2-\text { tailed }) \\
<0,05\end{array}$ \\
\hline
\end{tabular}

Based on Table 6, it can be concluded that there is a significant difference between critical thinking dispositions of students who take the guided discovery learning and conventional learning.

The results showed that the critical thinking skills and critical thinking dispositions of students in guided discovery learning were better than in conventional learning. This is an appropriate result if we analyze the stages in discovery learning. This learning begins inductively through the giving of problems in the student worksheet. The problems given to the students in this research are non-routine mathematics problems and ill-structure. This problem requires students to interpret the problem situation, create and test the conjecture, analyze, generalize, and conclude the solution. 
When students interpret problem situations, students explore the knowledge they have to understand the problem. Next, the students identify the related concepts and set the concepts to solve the problem. Furthermore, the generalization and clarification process of solutions that have been obtained need to be done by students in determining the right result. Through this activity, students are stimulated to think critically and have a high disposition, so that the right solution can be found.

Providing problems that train the ability to think critically continuously makes students better in understanding the concept. Understanding the concept in depth makes students using the strategy and making the right conclusion, so that learning is more meaningful for students. In addition, with students' understanding, their selfconfidence will also increase.

The second stage of discovery learning is the formulation of the problem. This step is to train students to explore what they will learn. In addition, students will learn to generalize the newly acquired information. It helps students to develop their critical thinking skills.

The third stage is the process of discovery. Discovering concepts by students in this learning are done through the stages of processing, organizing, and analyzing data provided by the teacher. When students are in the process of discovery, understanding is built on the knowledge that the students construct themselves. This is as John Dewey put in the theory of constructivism. In the process of discovery, sometimes teacher guidance is still needed to direct students to the goals to be achieved. Through the questions raised by the teacher, students can build confidence to empower their abilities. When students interact with their friends, they can measure their ability. When their friends manage to do a good job, they will have a good judgment about their ability to do the same task. Thus, students' self-confidence can develop. This is consistent with Zeldin (2000) who said that by observing the success of others, students can do an assessment of their own ability; so that the process of selfconfidence can develop.

Social intelligence of students is seen when they interact with peers in the group. With the social intelligence, students can interact better with their peers and students have the courage to express their opinions. When students dare to express their opinions, it means that the students' self-confidence has grown.
This is in accordance with the opinion of Goleman \& Widodo (1999) who argued that social intelligence helps a person to interact better. Thorndike in Goleman \& Widodo (1999) stated that social intelligence is the ability to understand and organize people to act wisely in relationships with others. Based on this opinion, social intelligence is an intelligence that encompasses group interaction and is closely related to socialization. Social interaction depends heavily on one's ability to know oneself and to know others. Someone who is skilled in social intelligence can connect with others well. They are able to read the reactions and feelings of others, able to lead and organize, and able to deal with conflicts that arise in relationships with others. Thus, social intelligence is also a person's ability and skill in creating, constructing, and maintaining his/her social relationships, so that both parties are in a favorable situation.

Introduction of group work in the discovery process creates social interaction between peers, which impact on students' mathematics critical thinking skills. It is appropriate with constructivism learning expert opinion, Vygotsky, who stated that social interaction can encourage the formation of new ideas and enrich the intellectual development (Yohanes, 2010). In relation to the learning of mathematics, the intellectual ability of students will develop through social interaction with others who are good at mathematics. Based on these descriptions, it can be concluded that social interaction gave rise to social intelligence that affects the child's intellectual abilities.

The fourth stage of discovery learning is the students put the conjectures of analysis done previously. In compiling this conjecture, students think critically in order to obtain a better answer and meticulous. This activity will help students identify and establish the truth of the concept of their prior knowledge. Prior knowledge refers to facts or information that students have learned or acquired through prior experience. When students are exposed to new learning tasks, they have some forms of "prior knowledge" in the head, allowing them to quickly connect what they are learning to what they already knew. Thus, the critical thinking skills of students will increase. Furthermore, students are required to present the results of their work.

The fifth stage, after the students presented the results, teacher checks whether 
students have made forecasts. This is done to ensure the truth of forecasts of students, so the direction taken is not wrong and headed to be achieved. Verbal persuasion from teachers can build self-esteem of students, so students' selfconfidence increases. Verbal persuasion is seduction or suggestion given to a person to believe that he / she can overcome the problems they faces. This verbal persuasion can lead a person to try more diligently in achieving goals and success. However, self-efficacy that grows with this method usually does not last long. Therefore, the students must get a continuous strengthening.

The sixth stage of guided discovery learning is the students put the truth forecasts. These activities help students to clarify misconceptions and establish conclusions about the problems that have been resolved in the previous stage. As indicated by Ojose (2015), "misconceptions exist in part because of students' overriding need to make sense of the instruction that they receive". At this stage, the students assess the extent to which the achievement of their performance during the learning process.

From the above exposure, it can be seen that each stage in guided discovery learning model provides an opportunity for the building of critical thinking skills and critical thinking dispositions. If teachers can make good use of opportunities in guided discovery learning, students' critical thinking skills and critical thinking dispositions can be improved.

\section{CONCLUSION}

The results from this research showed that the guided discovery learning can enhance mathematics critical thinking skills and critical thinking dispositions. Descriptive and inferential analysis results showed an increasing in students' mathematics critical thinking score and significant difference in critical thinking dispositions scale of students after following the guided discovery learning. This increase is included in a quite effective category. This proved that guided discovery model can be used as an alternative to improve students' critical thinking skills and critical thinking dispositions.

\section{REFERENCES}

Abdurahim, A. (2016). Keefektifan model pembelajaran resik ditinjau dari sikap, motivasi, dan kemampuan berpikir kritis matematis siswa SMP. Jurnal Riset
Pendidikan Matematika, 3(2), 137-149. https://doi.org/10.21831/JRPM.V3I2.7994

Balım, A. G. (2009). The effects of discovery learning on students' success and inquiry learning skills. Eurasian Journal of Educational Research Egitim Arastirmalari-Eurasian Journal of Educational Research, 35(35), 1-20. Retrieved from http://www.ejer.com.tr/0DOWNLOAD/p dfler/eng/1177009234.pdf

Chance, P. (1986). Thinking in the classroom: A survey of programs. Teachers College Press.

Ennis, R. H. (1987). A taxonomy of critical thinking dispositions and abilities. In J. B. Baron \& R. S. Sternberg (Eds.), Teaching thinking skills: Theory and practice (pp. 9-26). New York, N.Y.: WH Freeman/Times Books/Henry Holt \& Co.

Facione, N. C., \& Facione, P. A. (1996). Externalizing the critical thinking in knowledge development and clinical judgment. Nursing Outlook, 44(3), 129136. https://doi.org/10.1016/S00296554(06)80005-9

Facione, P. A. (1990). Critical thinking: A statement of expert consensus for purposes of educational assessment and instruction. Research findings and recommendations. Millbrae, CA: The California Academic Press.

Facione, P. A. (2000). The disposition toward critical thinking: Its character, measurement, and relationship to critical thinking skill. Informal Logic, 20(1), 6184. https://doi.org/10.22329/il.v20i1.2254

Facione, P. A., Facione, N. C., \& Giancarlo, C. A. F. (1996). The motivation to think in working and learning. New Directions for Higher Education, 1996(96), 67-79. https://doi.org/10.1002/he.36919969608

Facione, P. A., Sanchez, C. A., Facione, N. C., \& Gainen, J. (1995). The disposition toward critical thinking. The Journal of General Education, 44(1), 1-25.

Goleman, D., \& Widodo, A. T. K. (1999). Kecerdasan emosi untuk mencapai puncak prestasi. Jakarta: Gramedia Pustaka Utama.

Halpern, D. F. (2013). Thought and knowledge: An introduction to critical thinking. New 
Jersey, NJ.: Psychology Press.

Ibrahim, I. (2011). Pengembanagan kemampuan berpikir kritis dan kreatif siswa SMP dalam matematika melalui pendekatan advokasi dengan penyajian masalah open ended. Universitas Pendidikan Indonesia.

Innabi, H. (2003). Aspects of critical thinking in classroom instruction of secondary school mathematics teachers in Jordan. In The Mathematics Education into the 21st Century Project Proceedings of the International Conference (pp. 124-129). Brno. Retrieved from http://math.unipa.it/ grim/21_project/21_ brno03_Innabi.pdf

Kennedy, M., Fisher, M. B., \& Ennis, R. H. (1991). Critical thinking: Literature review and needed research. In L. Idol \& B. F. Jones (Eds.), Educational values and cognitive instruction: Implications for reform (pp. 11-40). Hillsdale, NJ: Lawrence Erlbaum.

Kilic, H. E., \& Sen, A. (2014). Turkish adaptation study of UF/EMI critical thinking disposition instrument. Ë̆itim ve Bilim, 39(176), 1-12. https://doi.org/10.15390/EB.2014.3632

Liberma, L. (2013). Pengembangan bahan ajar dengan pendekatan scientific untuk meningkatkan kemampuan berpikir kritis matematis dan self efficacy siswa. Universitas Negeri Medan.

Lipman, M. (1988). Critical thinking- what can it be? Educational Leadership, 8(1), 3843. Retrieved from http://www.ascd.org/ASCD/pdf/journals/e d_lead/el_198809_lipman.pdf

McLaren, P., \& Baysal, B. (2007). Kapitalistler ve işgalciler: Imparatorluğa karşı eleştirel bir pedagoji. Istanbul: Kalkedon.

Noddings, N. (2004). War, critical thinking, and self-understanding. Phi Delta Kappan, 487-495. Retrieved from http://journals.sagepub.com/doi/pdf/10.11 77/003172170408500705

Nosich, G. (1994). Where to begin: How to design classes to teach for thinking. Educational Vision, 2(2), 20-21.

Nursyahidah, F., \& Albab, I. U. (2017). Investigating student difficulties on integral calculus based on critical thinking aspects. Jurnal Riset Pendidikan Matematika, $\quad 4(2), \quad 211$. https://doi.org/10.21831/jrpm.v4i2.15507

Ojose, B. (2015). Common misconceptions in mathematics: Strategies to correct them. University Press of America.

Ragatz, A. B. (2010). Di dalam ruang kelas matematika di Indonesia: Studi video TIMSS tentang kegiatan pembelajaran dan capaian siswa. Jakarta: Bank Dunia.

Schaefer, M. P. (2012). Determining methods for teaching character education in elementary schools. Northcentral University. Retrieved from https://search.proquest.com/openview/c67 053078791db9abd6243b209ea3410/1.pdf ?pqorigsite $=$ gscholar $\& \mathrm{cbl}=18750 \&$ diss $=\mathrm{y}$

Uygulamaya, K., \& Demirel, Ö. (2002). Ĕ̈itimde program geliştirme. Ankara: Bask1, Pegem A Yayıncılık.

Yang, E. F. Y., Liao, C. C. Y., Ching, E., Chang, T., \& Chan, T.-W. (2010). The effectiveness of inductive discovery learning in 1: 1 mathematics classroom. In Proceedings of the 18th International Conference on Computers in Education (pp. 743-747). Putrajaya, Malaysia: AsiaPacific Society for Computers in Education. Retrieved from http://lexitron.nectec.or.th/public/ICCE 2010 Putrajaya Malaysia/ICCE2010 Main Proceedings/c6/short paper/C6SP200.pdf

Yohanes, R. S. (2010). Teori Vygotsky dan implikasinya terhadap pembelajaran matematika. Jurnal Widya Warta, 34, 854-1981.

Zeldin, A. L. (2000). Sources and effects of the self-efficacy beliefs of men with careers in mathematics, science, and technology. Emory University. 